IZA DP No. 8927

Household Migration and Child Educational Attainment: The Case of Uganda

Lucia Ferrone

Gianna Claudia Giannelli

March 2015 


\title{
Household Migration and Child Educational Attainment: The Case of Uganda
}

\author{
Lucia Ferrone \\ UNICEF Innocenti Research Centre
}

Gianna Claudia Giannelli

University of Florence,

CHILD and IZA

\author{
Discussion Paper No. 8927 \\ March 2015
}

\author{
IZA \\ P.O. Box 7240 \\ 53072 Bonn \\ Germany \\ Phone: +49-228-3894-0 \\ Fax: +49-228-3894-180 \\ E-mail: iza@iza.org
}

\begin{abstract}
Any opinions expressed here are those of the author(s) and not those of IZA. Research published in this series may include views on policy, but the institute itself takes no institutional policy positions. The IZA research network is committed to the IZA Guiding Principles of Research Integrity.

The Institute for the Study of Labor (IZA) in Bonn is a local and virtual international research center and a place of communication between science, politics and business. IZA is an independent nonprofit organization supported by Deutsche Post Foundation. The center is associated with the University of Bonn and offers a stimulating research environment through its international network, workshops and conferences, data service, project support, research visits and doctoral program. IZA engages in (i) original and internationally competitive research in all fields of labor economics, (ii) development of policy concepts, and (iii) dissemination of research results and concepts to the interested public.
\end{abstract}

IZA Discussion Papers often represent preliminary work and are circulated to encourage discussion. Citation of such a paper should account for its provisional character. A revised version may be available directly from the author. 


\section{ABSTRACT \\ Household Migration and Child Educational Attainment: The Case of Uganda}

In many Sub-Saharan African countries, a large number of people migrate internally or abroad because of demographic, economic and political factors. This pronounced mobility is likely to have consequences for child education, which is still a matter of concern in the region. We study this issue for Uganda, investigating whether the migration of household members affects child primary education and in what direction. Using the Uganda National Panel Survey for 2005, 2009, 2010 and 2011, we estimate conditional fixed effects logit models of school attendance and primary school completion. We find that migration of children has a significant positive impact on child school attendance rates while that of adults has a significantly negative effect, and that remittances have no influence. These findings suggest that migration of children is indeed beneficial, since it may contribute to matching the demand and supply of schooling. The absence of adults, instead, has controversial effects when children are left behind. In fact, lack of supervision and children working substituting adults in their tasks might reduce the rate of school attendance. However, the migration of neither children nor adults seem to increase the rate of primary school completion, evidence that points to the problem of the low quality of primary education in developing countries.

JEL Classification: $\quad$ I25, J13, J61, O15

Keywords: migration, schooling, panel data models with fixed effects, Uganda

Corresponding author:

Gianna C. Giannelli

Department of Economics and Management

Università di Firenze

Via delle Pandette 9

50127 Firenze

Italy

E-mail: giannelli@unifi.it 


\section{Introduction}

Primary education is a major issue for developing economies. A lack of infrastructure and government funds, and often institutional frailty, take a severe toll on achieving universal education. Nevertheless, education is widely recognized as a key factor in human capital formation, and therefore a basic element of economic growth. A well-known phenomenon in developing countries is that while school attendance is generally widespread among young children, problems arise in completion of elementary school because of delays in enrolment, grade repetition and particularly dropout before completion of the entire cycle. A combination of different problems arising from both the demand and the supply sides of education (Handa, 2002), contributes to this critical situation. Among the possible causes are the opportunity costs associated with the foregone income from child labour (Edmonds, 2008), chronic shortages of well-trained teachers (UNESCO, 2013) and school fees (UNICEF, 2009).

In this paper, we investigate the relationship between household migration, defined as all internal and international residential changes of household members including children, and child educational outcomes in terms of school attendance and school completion. Our focus is on the effects on elementary school attendance and completion, since in developing countries dropout rates in the first grades are still very high. We distinguish between migrations of adults and children, with the aim of disentangling their respective influences on child primary school attainment.

The economic literature on migration has largely focused on the effects of remittances on child wellbeing. With few exceptions, remittances are found to increase schooling and reduce child labour. Remittances from abroad have a large positive impact on school retention in El Salvador (Edwards and Ureta, 2003), but when the endogeneity of the migration decision is controlled for this effect disappears (Acosta, 2011). Increased receipts of overseas remittances due to favourable exchange rate movements in the Philippines increases child schooling 
and educational expenditure and reduces child labour (Young, 2008). Both migration and remittances reduce child labour in the Kagera region in Tanzania (Dimova et al, 2011), and in the rural areas of Ecuador remittances in conjunction with aggregate shocks, such as droughts and damage to agricultural production due to frost and plagues, increase school enrolment and decrease child labour, especially for girls (Calero et al, 2009).

Most of the time, however, remittances are sent by household members that have left the household. If they are parents, part of the monitoring of children's education is lost. If only one parent migrates, the remaining parent can be loaded with extra duties, thus further reducing the supervision of children. Moreover, parental absence may require children (especially older children) to substitute their missing parent in domestic or agricultural tasks, thus neglecting their schooling. A number of studies highlight these negative sideeffects of the international migration of parents. Absence of the father results in dropout or repeating grades in Albania, and the impact is worse for girls than for boys, implying that migration of parents can reduce gender equality and the empowerment of women (Giannelli and Mangiavacchi, 2010). Similar effects on the schooling of girls and boys are found in the rural areas of Mexico (McKenzie and Rapoport, 2011). The evidence is, however, mixed on the gender inequality issue. The migration of Mexican fathers to the US is correlated with additional education for girls (Antman, 2012). Furthermore, disruptive effects may emerge from leadership changes in the family. In a traditional setting, fathers and mothers supervise their children's education, but if they are absent it is likely that the decision power shifts to older men and women in the household, who may be less educated and less likely to understand the value and importance of human capital, especially for girls (Ginther and Pollak, 2004).

We study the case of Uganda. Like several other Sub-Saharan African countries, Uganda is characterized by intense flows of internal mobility and international migration towards 
the neighbouring countries. These migrations flows are prompted by demographic, economic and political factors, with wars having a dramatic role, forcing the migration of refugees and internally displaced persons. We use data drawn from the Uganda National Panel Survey for 2005, 2009, 2010 and 2011, which show that during the 2000s on average more than 20 per cent of households have at least one member with a migration experience. Notwithstanding the well-known urbanization phenomenon, Uganda remains largely rural and most migrations take place from one rural area to another. This pronounced household mobility is likely to have consequences for child education, which is still a problematic issue in the country. To our knowledge, no study has looked at the effect of migration on education in Uganda and we aim to contribute in this sense.

We also aim to contribute in other ways. Unlike the literature reviewed, in this paper we study the effects on schooling of past and current migration experiences of adult and child household members. From a theoretical point of view, since migration and child education cannot be understood as individual decisions, but must instead be regarded as collective decisions made by the extended family, we conduct our analysis at the household level, focusing on household rates of schooling and migration. More practically, this choice also allows us to maximize the number of panel households observed we can count on to estimate our fixed effects models. Moreover, methodologically, the availability of panel data allows us to overcome the identification problem usually found when dealing with these types of issue, as people who decide to move may differ from those who do not, thus self-selecting in ways that cannot be captured by the available data. The availability of longitudinal data, therefore, allows us to tackle the problem of unobserved heterogeneity present in all the studies reviewed which are based on cross-sectional data. Another advantage of the data we use is the availability of information on the migration of household members in the five years before the date of the interview. This 'lagged' information provides another way to tackle the 
problems connected with the endogeneity of the decision to move with respect to schooling choices. Our findings show that family migration has a composite effect: if adults move and children are left behind it has a negative impact on school attendance, while if children move (either alone or with their parents) it has a positive effect. These results are not unexpected, since a major reason for moving is to reach areas with better services and opportunities, and often in Africa also to escape from areas disrupted by civil conflicts. When adults move from the household leaving children behind, on the other hand, it has a detrimental effect on schooling, probably due to a lack of supervision of the children, and to the fact that often they have to substitute adults in household chores. The paper is organized as follows: the next section motivates the choice of Uganda as a case study. The following three sections present the empirical models, the data and the results. The last section concludes.

\section{The case of Uganda}

Uganda is an eastern African country, an area whose economy still lags behind. GNI per capita is lower than the average of the Sub-Saharan countries, even though poverty levels have been falling in recent years ${ }^{1}$ Uganda has a low Human Development Index (HDI), ${ }^{2}$ ranking 164th out of 187 countries, and 30th out of 50 African countries. On the one hand, the structural reforms which started in the 90 s took their toll on the population: a widespread liberalization and privatization of the agricultural market led to a worsening of the living conditions for a large part of the population, which still survives on agriculture and herding. On the other hand, the fragile social and institutional context have prevented the programmes implemented by the World Bank and the IMF from being effective, especially the programmed government decentralization.

The choice of Uganda as a case study of the relationship between migration and education is justified by two main motivations. Regarding education, universal primary education is 
still a problematic goal in Uganda, even though gross enrolment ratios have risen in recent years. The majority of Ugandans either have no formal education or only some primary education. In 2011, 20 percent of females and 13 percent of males aged 6 and older had never had any formal education. Low levels of education still persist among young people: the highest level of education of 54 per cent of females aged 15-19 is only a primary grade, for 10 per cent it is completed primary education, and for 30 per cent it is uncompleted secondary education (UBOS and ICF, 2012).

In 1997, Uganda undertook a major reform programme under the name Universal Primary Education (UPE), which abolished fees for primary enrolment with the goal of ensuring that up to four children per family were able to attend school. At the same time, a part of the programme was devoted to dissemination, awareness building and decentralization at the local level. The programme was associated with a dramatic increase in enrolment, especially for girls (Deininger, 2003). Moreover, the elimination of school fees had significant positive effects on the timely enrolment of girls and children living in rural areas. In fact, considering that school entry at ages above eight is very strongly associated with early school dropout, the UPE programme was found to result in a 3 per cent increase in the probability of a child beginning to attend school before age nine (Grogan, 2008). These results demonstrate that such programmes are effective in poor countries, where even a small tuition fee is an obstacle to school attendance. On the downside, probably because of the fast pace of the programme, the quality of schooling did not improve at the same rate. Student-teacher ratios increased sharply, and in 1999 about a quarter of the students failed the primary school final examination. UPE programmes should therefore be complemented with measures that improve progress to higher grades and the acquisition of additional skills in each grade. Evidence drawn from surveys since 2009 monitoring school outcomes in terms of test scores show that many East African children remain illiterate or innumerate, despite having completed 
multiple years of school. Among East African countries, Uganda performs best in terms of enrolment but worst in terms of learning outcomes (Jones et al, 2014). A rough indication of the efficacy of the primary education system can be drawn from the primary completion rate. As shown in Figure 1, during the first decade of 2000 this rate was quite low, and there is no tendency towards a reduction of the dramatic gap with respect to the gross enrolment rate.

\section{INSERT FIGURE 1 HERE}

As far as migration is concerned, the Ugandan population shows high rates of internal migration, often caused by external shocks. Uganda has a very fractured society; it is one of the most divided among Sub-Saharan countries, with ethnic, linguistic and religious divisions deeply rooted in its colonial history. ${ }^{3}$ There are economic disparities between the north and the south-western region of the country, with the latter being the wealthier. Civil strife has been going on in the northern region since the 1980 s and is still continuing. ${ }^{4}$ At the end of the 1990s, it was estimated that between 800,000 and 1,000,000 people were killed by state terror, ethnically-motivated violence and civil strife. It is also estimated that around a million refugees were displaced from their homes in those years. This led to increasing internal migration, making Uganda a relevant case for our topic of analysis. ${ }^{5}$ International migration, instead, is a rather rare phenomenon and even more so international migration toward non-African countries. On a population of about 36 million people, the biggest community of migrants from Uganda was in Kenya and counted roughly over 500,000 people in $2010 .^{6}$

Another type of internal migration is children migrating independently of parents in the majority of cases a phenomenon overlapping with child fostering (children living in households with neither their mother nor their father present). In Africa, child fostering is a common institution: evidence drawn from surveys for West Africa show that at least 15 
per cent of households have one or more children under 15 living without their (biological) parents (Pilon, 2003). In Uganda, the percentage of households with foster children under 18 years of age is 28.623 .8 per cent residing in urban areas and 29.7 per cent in rural areas (UBOS and ICF, 2012). In many cases fostered children have moved from households that face difficulties enrolling them in school to households where school enrolment is less problematic. Evidence drawn from a survey conducted in 1993 in South Africa shows, for example, that child fostering reduced the risk of not attending school by up to 22 per cent (Zimmerman, 2003).

In sum, internal migration is a widespread phenomenon that occurs for reasons of work or marriage in the case of adults, while for children the main reasons are education and following or rejoining their families.

\section{The estimation strategy}

We aim to measure the relation between family migration and child schooling in terms of school attendance and school completion. The use of panel data ensures a control for unobserved factors and self-selection, which are well-known issues when dealing with both educational outcomes and migration. Education is influenced by natural ability, an unobserved and unobservable factor, while families with a higher predisposition to move may be, in fact, different from other families in a way that affects both moving and education, thus creating a self-selection problem. The basic model at the individual level is the following:

$$
y_{i j t}=\beta_{0}+\beta X_{i j t}+\gamma M_{i j t}+\delta Z_{j t}+u_{i j}+\eta_{j}+\epsilon_{i j t}
$$

The outcome $y$ of individual $i$ of household $j$ at time $t$ is determined by individual characteristics $\mathrm{X}$, the migration variable at the individual level $\mathrm{M}$, household characteristics 
$Z$, an individual fixed effect $u_{i j}$ and a household fixed effect $\eta_{j}$. The household fixed effect captures the household attitude towards child education, which might be either unobserved (i.e. not available in the survey) or unobservable. The problem with this model, beside the difficulty of tracking both individual and household fixed effects over time, is that the second to the fourth waves of the panel are very close in time (2009, 2010 and 2011) and the variability of outcomes at the individual level might be very low, a problem that might be amplified when the dependent variable is a dummy and not a continuous one. To overcome these problems, we estimate the following household-level model:

$$
\bar{y}_{j t}=\beta_{0}+\beta \bar{X}_{j t}+\gamma \bar{M}_{j t}+\delta Z_{j t}+\eta_{j}+\bar{\epsilon}_{j t}
$$

Individual characteristics are substituted with household averages of the same characteristics, so that the outcome y is actually the average school attendance (or school completion) of children aged $6-15$ in household $\mathrm{j}$. It can also be interpreted as the household-specific rate of school attendance, or as the probability of a child aged 6 to 15 in household $\mathrm{j}$ attending school at time t. In substance, this is a model of the household's general attitude towards its child members. From the conceptual point of view, since schooling decisions regarding children are taken by adults, this specification is more relevant for our research question than the individual (child) specification. Moreover, as will be explained later in the paper, the migration variables are defined at the household level. ${ }^{7}$ From the methodological point of view, this model allows us to take into account household effects (using a fixed effects specification), and reduces the problem of little variability across close waves. The model can be estimated with a linear probability model with fixed effects. However, as the dependent variable is continuous but truncated at both ends, the model is also estimated using a two-side censoring model for panel data (Alan et al, 2011), which is useful when the dependent variable is a fraction, as in this case. The two-side censoring model is based, like 
censoring models in general, on the idea of a latent variable $\mathrm{y}^{*}$ which conditions the observed variable $\mathrm{y}$, so that we have:

$$
y^{*}=\beta^{\prime} \mathbf{X}+\epsilon
$$

where we observe

$$
y= \begin{cases}L & \text { if } y^{*}<L \\ y^{*} & \text { if } L \leq y^{*} \leq U \\ U & \text { if } y^{*}>U\end{cases}
$$

and $\mathrm{L}$ and $\mathrm{U}$ are the lower and upper limits.

\section{Data and Variables}

We draw our sample from the four waves of the Uganda National Panel Survey (UNPS) collected in 2005-06, 2009-10, 2010-11 and 2011-12. The survey is a part of the World Bank Living Standard Measurement Study programme. The four waves collect data from a national representative sample. Table 1 presents the number of households and individuals surveyed in each round.

\section{INSERT TABLE 1 HERE}

The survey collects much information on the socio-demographic, education, work and consumption characteristics of households and their members. The section devoted to migration and the migration history of the household provides information about previous places of residence and the length of stay in the current place of residence of household members. The problem related to this section of the questionnaire (Section 3) is that it changes slightly between the first round and the next three, which are much more even in 
structure and coding. The only way to obtain a homogeneous variable across the four waves was to specify our key migration variable as a dummy that takes value 1 if the household member has changed place of residence in the last five years.

The main key dependent variables are two dummies: 1) school attendance at the time of the interview for all children aged 6 to 15 years; and 2) completion of elementary school for all children aged 11 to 15 . Table 2 shows their distribution. In order to better understand child outcomes, we decided to add a third dependent variable: the proportion of idle children in the household. Idle children are defined as children neither attending school nor working. ${ }^{8}$ Our sample confirms the evidence reported in Fig.1: a high enrolment ratio, but a low completion rate. As for child migration in the five years before the interview, this affected 9 per cent in 2005, 17 per cent in 2010, 15 per cent in 2011 and almost 13 per cent in 2011.

\section{INSERT TABLE 2 HERE}

We estimate a fixed effects household model. As already mentioned, this has the advantage of capturing household-specific effects, which are crucial given that child schooling is a family decision rather than an individual one. Having decided to conduct our analysis at the household level, our dependent variables are the household rate of child school attendance and school completion. This choice, despite on the one hand having the disadvantage of leading to a loss of child-specific information, on the other hand has the advantage of allowing us to sample all the panel households with children in the selected school-age range. If we had chosen to conduct a child-specific analysis, given the time distance between the surveys, our sample would have been severely constrained by the limited number of panel children who remain in the school-age range in the three rounds of the survey. Furthermore, the household level specification also solves the problem of the individual specification models: because the last three waves are very close in time, and because the 'yes' (i.e. the 1 values) observations in the mobility variable are few for the children's age group, the explicative power of the 
individual fixed effect model, which relies on differences among different years, is very low. More importantly, the variation in the outcomes is very low as well, resulting in an extreme reduction in observations. Using household-level observations allows us to overcome both these problems. ${ }^{9}$

First of all, we need to define the new dependent variables, which are defined as follows for each household i :

$$
\text { Schooling }=\sum_{i=1}^{I} y_{i j t} I
$$

Where $I$ is the total number of children aged 6-15 in household $j$, and $y_{i j t}=1$ if child $i$ goes to school, 0 otherwise. The same method is used for all dependent variables, changing the denominator $I$ as the age range changes. This is also how all the other control variables at the household level are constructed, always changing I according to the type of variable. Basically, these are household averages of individual-level variables. Consequently, the schooling variables can take the following values:

$$
\text { Schooling }= \begin{cases}1 & \text { if } y_{i j t}=1 \forall i \\ 0 \leq \text { Schooling } \leq 1 & \text { if } y_{i j t}=1 \text { for at least one i } \\ 0 & \text { if } y_{i j t}=0 \forall i\end{cases}
$$

As for mobility $M$, a crucial point for this model is to define it at the household level. This is a conceptual question rather than a computational one. This variable records migration in the previous five years of currently present (and interviewed) members of the household. ${ }^{10}$

The most straightforward solution would be to use a household average number of 'movers', but that in turn raises the question of how to calculate such an average: whether for children, or for all of the household members. The best solution in this case is not to 
use an average but instead two dummy variables: the first one takes value 1 if at least one adult member (aged 16 and above) has left the household in the previous five years, and 0 otherwise. The second one takes value 1 if at least one child has moved in the previous five years, and 0 otherwise. Moreover, as the two variables are used simultaneously in the models, it is possible to control for the possibility that both children and adults have moved together, as opposed to cases in which only adults or only children have moved. In theory, they could be highly correlated, but they are not: the correlation between the two variables is 0.29 , which can be regarded as reasonably low. This tells us that adults and children do not always move together, as in the case of fostering discussed above. Another interesting feature of this migration variable is that it tackles migration in a retrospective way: the question about previous migration is asked of each individual that is present at the time of the interview, i.e. individuals that have come back to the household where they were residing before migration, and individuals that have all moved together to the place of residence where they are interviewed. Therefore, the variable assesses the household past migration propensity, which is likely to have affected schooling decisions regarding school-age children in the household. Since this variable does not cover family members currently living elsewhere, to proxy the phenomenon of currently absent household members, we also introduce two additional dummies: one that takes value 1 if at least one adult is currently absent and 0 otherwise; and one analogous dummy for absent children. This current migration indicator, however, is likely to suffer from the remaining endogeneity problems due to time-varying unobservables that cannot be controlled for by our fixed effects estimation method. We also control for two reasons for child migration: for education or for work. The percentage of children who changed residence to attend school is not irrelevant: as previously discussed, in Uganda it is not uncommon for children to leave their families and move to live with relatives or acquaintances in order to attend school. The percentage of children who migrate 
to work, instead, is much lower.

The other control variables are described in Table 3, along with their descriptive statistics (means and standard deviations).

\section{INSERT TABLE 3 HERE}

The average education level of adult women is the probability of adult women in the household having at least completed elementary school, and it is constructed in the same way as the previous averages. As for wealth and income, the data only provide expenditure quintiles, which are calculated using the questionnaire section on household expenditure, and are divided by the square roots of the number of household members to obtain per capita expenditures. ${ }^{11}$ One thing that is important to address is the number of female children in our sample. As we can see from Table 3, the percentage is well below the natural gender ratio. After having controlled for gender ratio in the cross sections and for selective infant mortality, we conclude that this is due to sample attrition: girls are more likely to leave the household and not come back. Even though we do not have information on the reasons why these girls left, it is highly probable that the older ones left in order to marry. ${ }^{12}$ However, this does not represent an insuperable problem for our model, since older girls are very unlikely to attend school somewhere else. We can assume that the choice to marry them is equivalent to the choice to not send them to school. We see some evidence of this type of positive gender selection in our results, as a higher proportion of female children in the household results in a higher attendance rate.

Table 4 presents the summary statistics for each cross-section, for migrant vs. nonmigrant households. We define a household as migrant if it has at least one usual member that has previously moved or is currently absent.

\section{INSERT TABLE 4 HERE}

As we can see, there are significant differences among migrant and non-migrant house- 
holds for the majority of the control variables: migrant households tend to be richer, for example, and the head of a migrant household is more likely to be better educated. The fact that the two groups show significant differences in almost all the controls and dependent variables supports the use of a fixed effects model.

\section{Results}

Table 5 shows the results of the estimated linear probability model of the household school attendance rate.

\section{INSERT TABLE 5 HERE}

The past migration variable for children has a positive and significant effect in all the model specifications, while the current migration state of adult household members has a negative effect. Moving benefits children, while adults' decisions to move and leave children behind have a negative effect on children's current school attendance. If household members have a past migration history, this does not affect the current school attendance of children. Absence of at least one child at the time of the interview has a positive effect (at 5 per cent significance level) on school attendance, coherently with the result that a smaller number of household members, both children and adults, increases the probability of attending school (see the coefficients for the number of children aged 6-15 in the household, and for the number of adults).

In our setting, therefore, children's migration history has lasting effects on their school attendance, thus supporting the hypothesis that migration also helps by matching the supply and demand for educational services. On the other hand, a current absence of adults has immediate negative effects, most probably due to a lack of supervision and children substituting in the tasks previously performed by currently absent adults. While the result for child migration to the best of our knowledge constitutes a new piece of evidence, the result 
for adult migration is in line with what is found in the literature on children left behind. We add to this latter evidence, however, by disentangling the current from the lagged effects of adult migration.

At variance with evidence for other countries, remittances do not significantly increase the probability of the children in the household attending school. This result is not surprising, since in Uganda migration is mainly internal while the findings of most of the literature concern remittances from international migrants. As already mentioned, internal migration in Africa is for many different reasons, and probably the motivation of sending money to the household of origin is not the prevailing one. ${ }^{13}$

Given the importance of the urbanization process, it might be the case that household migration towards urban areas is also motivated by a need to move to areas where schools are more numerous and of better quality. We therefore separate rural to urban household migration from other migration directions in order to verify whether this type of move increases the probability of schooling. At variance with some descriptive and cross-sectional evidence for other countries showing that this is the case (see, for example, Ackah and Medvedev (2010) for Ghana),we do not find any significant effect on school attendance of moving from rural to urban areas or vice versa. In the period studied, however, there was no evident urbanization process, since the percentage of household members who migrated from rural to urban areas was very similar to that of household members who migrated from urban to rural ones (around 20 percent). However, rural to rural migration was the most frequent case. ${ }^{14}$

In order to test whether migration is a way to reach areas with better services, we also distinguish between the two main motivations for the migration of children, namely for education or for work. The third column in Table 5 shows that having moved for educational 
purposes has indeed a positive and significant impact on current school attendance. We also distinguish between motivations for adults, but this does not add anything to the result, indicating that adult absence is relevant regardless of the reasons why adults have migrated. Another important factor to take into account might be distance between the origin and destination areas of migrants, since migrants who live nearby might more easily monitor their children left behind. However, since we estimate a household average model, a variable measuring the average distance of household members who have migrated does not seem to be meaningful for our purpose..$^{15}$

As already mentioned, the number of children aged 6 to 15 in the household has a negative effect, showing that there is competition for household resources among school age children. The other significant relevant covariates (namely, child age, average adult female primary education completion rate, number of adult members in the household and expenditure quintiles) have the expected signs, except for gender: being female, on average, seems to have a slightly positive effect on school attendance.

Table 6 shows the results for the two-side censoring model. Everything remains the same in terms of signs, and the significance level of the coefficients of interest is even higher, thus confirming the findings.

\section{INSERT TABLE 6 HERE}

Tables 7 and 8 report the results for primary completion estimated with the linear probability and the two-side censoring models respectively.

\section{INSERT TABLES 7 and 8 HERE}

No evidence of any migration effect on completing elementary school emerges. None of the migration variables are any longer significant, except for the positive effect of the current absence of children (as in Tables 5 and 6), which is coherent with the negative effect of the number of children aged 6-15 in the household. If children migrate it does not help 
them to complete primary school. On the other hand, adult migration does not have a negative effect, either. These two facts seem to suggest that completing school is much more a problem related to the quality of the supply of education.

These findings, however, could be a result of the age of the children. That is, migration does not affect children's school completion simply because children do not go to school. To check whether this is indeed the case, we run a separate regression on school attendance by age group; first for children aged 6 to 10, and then for those aged 11 to $15 .{ }^{16}$ Table 9 reports the results relative to the migration variables. We can see that the effect of a child's past migration is indeed stronger for older children, while it is non-significant for younger children. However, the absence of an adult is always detrimental for both age groups.

\section{INSERT TABLE 9 HERE}

Given these findings, a more general question concerning children's allocation of time arises. When children do not attend school, what do they do? One of the main problems in poor developing countries is not just child labour, but also children neither working nor attending school. In order to check for the effects of migration on these alternative allocations of time, we also estimate the same model both for child labour and for children aged 6 to 15 that are idle. We find no significant effect of migration on child labour. ${ }^{17}$ Instead, migration significantly affects the state of being idle, mirroring the result for school attendance: adult migration increases the household rate of child idleness, whereas child migration decreases it (see Tables 10 and 11).

\section{INSERT TABLES 10 and 11}

Interestingly, there is an indication that past adult mobility also has a positive effect on being idle (in the first two columns of Tables 10 and 11), while for school attendance current absence only matters (for idle children current adult absence is only significant at the 10 per cent level in Table 11). This could point to another effect to be further investigated besides 
lack of current supervision: whether past adult migration affects child idleness in a more lasting way if children stop attending school when adults are absent and then do not go back to school when they return.

As for the other control variables, the number of children living in the same household increases the probability of them being idle, to some extent validating general assumptions of competition over household resources. Women's education, on the contrary, has a negative

effect on the probability of children being idle. The household expenditure quintiles are all significantly negative.

In sum, the results for idle children are coherent with those for school attendance. They suggest, as emerges from other pieces of evidence (for example, Biggeri et al (2003)), that the main alternative to child schooling is children reporting doing nothing, and not child labour.

\section{Conclusions}

We have investigated whether household migration affects child primary education in Uganda in terms of school attendance and school completion. Panel data and retrospective information on migrations of household members have allowed us to overcome the usual problems of unobserved heterogeneity and endogeneity of migration decisions. Our findings for school attendance show that migration has a composite effect: if children move it has a positive effect on school attendance; if adults move and children are left behind it has a negative effect.

This evidence on the effect of child migration supports the hypothesis that when parents move with their children or send them to other households they make rational decisions that also aim, among other possible motivations, to improve their children's access to education.

Distinguishing between current and past adult migration when leaving children behind 
has highlighted two facts. First, a current absence of adults has negative effects on school attendance, probably due to a lack of supervision of children and them having to substitute adults in household chores. This is in line with evidence for other countries. Second, past migration of adults does not affect current school attendance, but negatively adds to the educational background of children, increasing the probability that children are currently idle.

Primary school completion, instead, is not affected by migration of either children or adults. This evidence seems to suggest that, notwithstanding household efforts to guarantee access to schooling, the final result in terms of the schooling outcomes of children is very poor. Not surprisingly, the question of how to improve the quality of the supply of education occupies first place on the policy agendas of many African countries.

\section{Acknowledgements}

We presented an earlier version of this paper in 2014 at the conference of the European Society for Population Economics in Braga and at the SITES-IDEAS (Italian Development Economists Association) conference in Florence. We wish to thank all the participants for their helpful suggestions.

\section{Notes}

${ }^{1}$ GNI per capita, PPP (current international US dollar), was 1,310 in 2011, and poverty 24.5 per cent in 2009 (percentage of population below national poverty line). Source World Bank.

${ }^{2}$ Source: Key to HDI countries and ranks 2013, Human Development Report. United Nations Development program, p.159, published in 2014.

${ }^{3}$ In Uganda, there are 53 officially recognized ethnic groups.

${ }^{4}$ Three armed groups are active in this area: the Lord's Resistance Army, the West Nile Bank Front 
(WNBF) and the Allied Democratic Forces (ADF).

${ }^{5}$ Unfortunately, forced displacement is not addressed in the present work, as data on civil strife and violence at the household level present many missing values. It is of course much more difficult to research households and individuals that have suffered displacement, but further research on this topic is certainly due.

${ }^{6}$ International Organization for Migration and World Bank, 2010.

${ }^{7}$ For similar reasons, Bargain and Boutin (2014) make the same choice for studying child labour and remittances in Burkina Faso.

${ }^{8}$ Working is defined as 20 or more hours per week of combined household and market work.

${ }^{9}$ We did, however, run an individual model as a robustness check, exploiting the availability of the fourth wave and using it to create more variation by skipping the third. The results hold.

${ }^{10}$ This information is drawn from UNPS 2009-10, 2010-11 and 2011-12 Section 3 ('Migration for all household members'), question 15: 'How many years has NAME lived in this place/village?'. It is transformed into a dummy that takes value 1 if the household member has been residing at the address of the interview for less than 6 years. The five years of uninterrupted residence threshold is chosen in order to harmonize the information with UNPS 2005-06. In UNPS 2005-6, in fact, the question was: 'Since 2001, has NAME lived in another place, such as another village, another town or country for 6 or more months at one time?'.

${ }^{11}$ This is alternative to equivalence scale methods, which require distinguishing between types of expenditure.

${ }^{12}$ In Uganda, the median age at first marriage is around 17 (UBOS and ICF, 2012).

${ }^{13}$ Unfortunately, we cannot investigate this point further, since the data contain too few observations of international migrants.

${ }^{14}$ These results are not presented but are available on request.

${ }^{15}$ Furthermore, defining and measuring distance with the UNPS is rather complicated. Using the information on the previous and current district of residence, one could construct an index based on this information. However, it is questionable whether this would be meaningful since administrative districts vary considerably in size, and simply having changed district of residence would not be a good proxy of distance.

${ }^{16}$ The remaining covariates are the same as in the previous models.

${ }^{17}$ Results available on request. We adopt a wider definition of child labour than UNICEF, according to which a child is considered to be involved in child labour activities as following: (a) children 5 to 11 years of age that during the week preceding the survey did at least one hour of economic activity or at least 28 hours 
of domestic work, and (b) children 12 to 14 years of age that during the week preceding the survey did at least 14 hours of economic activity or at least 42 hours of economic activity and domestic work combined. Here, we allow a little more leeway and children (aged 6-15) are defined as engaged in labour if they did more than 20 hours combined of housework or market work (paid or unpaid). 


\section{References}

Ackah C, Medvedev D (2010) Internal Migration in Ghana. Determinants and Welfare Impacts . Policy research working paper, World Bank 5273

Acosta P (2011) School Attendance, Child Labour, and Remittances From International Migration in El Salvador . Journal of Development Studies 47(6):913-936

Alan S, Honore' B, Hu L, Leth-Petersen S (2011) Estimation of Panel Data Regression Models with Two-Sided Censoring or Truncation. Federal Reserve Bank of Chicago, Working Paper 8

Antman F (2012) Gender, Educational Attainment, and the Impact of Parental Migration on Children Left Behind. Journal of Population Economics 25(4):1187-1214

Bargain O, Boutin D (2014) Remittances And Child Labour In Africa: Evidence From Burkina Faso . IZA Discussion Papers

Biggeri M, Guarcello L, Lyon S, Rosati F (2003) The Puzzle of 'Idle' Children: Neither in School, nor Performing Economic Activity . Understanding Children's Work (UCW)

Calero C, Bedi A, Sparrow R (2009) Remittances, Liquidity Constraints and Human Capital Investmentsin Ecuador . World Development 37(6):1143 - 1154

Deininger K (2003) Does Cost of Schooling Affect Enrollment by the Poor? Universal Primary Education in Uganda . Economics of education review 22(3):291-305

Dimova R, Epstein G, Gang I (2011) Migration, Transfers and Child Labor . IZA Discussion Papers 5641 
Edmonds E (2008) Handbook Of Development Economics, Elsevier, chap Child Labor, pp edition 1 , volume 4 , number 5

Edwards AC, Ureta M (2003) International Migration, Remittances, and Schooling: Evidence From El Salvador . Journal of Development Economics 72:429-461

Giannelli G, Mangiavacchi L (2010) Children's Schooling and Parental Migration: Empirical Evidence on the Left Behind Generation in Albania . Labour 24:76-92

Ginther D, Pollak R (2004) Family Structure and Children's Educational Outcomes. Blended Families, Stylized Facts and Descriptive Regressions. Demography 41(4):671-696

Grogan L (2008) Universal Primary Education and School Entry in Uganda. Journal of African Economies 18 (2):183-211

Handa S (2002) Raising Primary School Enrolment in Developing Countries. The Relative Importance of Supply and Demand . Journal of Development Economics 69:103-128

Jones S, Schipper Y, Ruto S, Rajani R (2014) Can Your Child Read and Count? Measuring Learning Outcomes in East Africa. Journal of African Economies 23 (5):643-672

McKenzie D, Rapoport H (2011) Can Migration Reduce Educational Attainments ? Depressing Evidence from Mexico . Journal of Population Economics 24(4):1331-1358

Pilon M (2003) Foster Care and Schooling In West Africa: The State Of Knowledge. Background paper for EFA Global Monitoring Report 2003/4, UNESCO publishing

UBOS, ICF (2012) Uganda demographic and health survey 2011. Tech. rep., Uganda Bureau of Statistics (UBOS), Kampala; ICF International Inc., Calverton, Maryland

UNESCO (2013) Addressing the Crisis in Early Grade Teaching. Education for All Global Monitoring Report Policy Paper 07, Paris 
UNICEF (2009) Abolishing School Fees in Africa, Lessons from Ethiopia, Ghana, Kenya, Malawi, and Mozambique

Young D (2008) International Migration, Remittances and Household Investment: Evidence from Phillipine Migrants Exchange Rates Shocks . Economic Journal 118(518):591-630

Zimmerman FJ (2003) Cinderella Goes to School. The Effects of Child Fostering on School Enrollment in South Africa. Journal of Human Resources 38 (3):557-590 
Table 1: Survey description

\begin{tabular}{ccc}
\hline Years & Number of households & Number of individuals \\
\hline $2005-06$ & 3,123 & 16,759 \\
$2009-10$ & 2,975 & 18,734 \\
$2010-11$ & 2,716 & 19,180 \\
$2011-12$ & 2,850 & 21,279 \\
\hline
\end{tabular}

Source: UNPS, Household Section (GSEC1, GSEC2). 
Figure 1: Gross Enrolment Ratio and Primary Completion Rate, Uganda

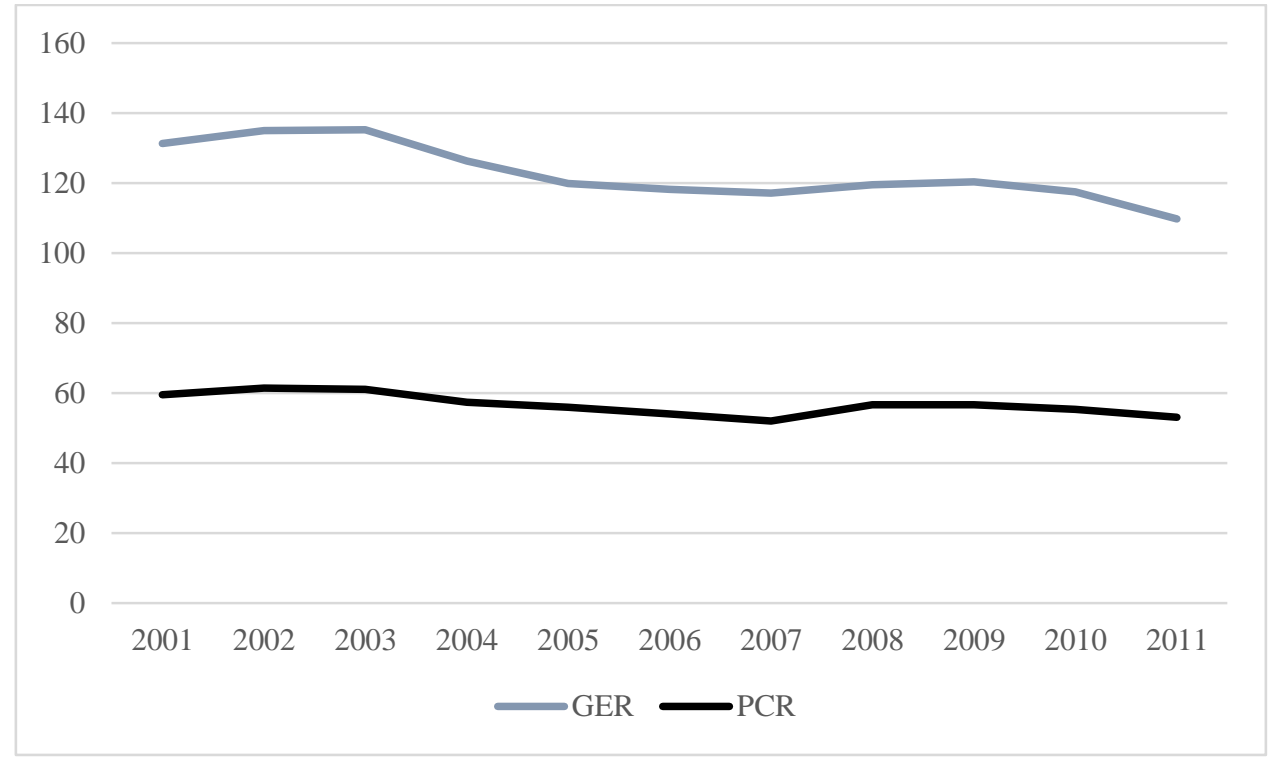

Note. GER: Gross enrolment ratio in primary education, both sexes (\%);

PCR: gross intake ratio to the last grade of primary education, both sexes (\%).

Source: UNESCO Institute for Statistics, at: http://data.uis.unesco.org/ 
Table 2: Distributions of migration and schooling variables in the cross sections

\begin{tabular}{|c|c|c|}
\hline & Absolute Frequency & Percentage $\%$ \\
\hline \multicolumn{3}{|l|}{ Moved in the last 5 years (children 6-15): } \\
\hline 2005-06 & 463 & 9.20 \\
\hline 2009-10 & 903 & 16.85 \\
\hline 2010-11 & 829 & 14.76 \\
\hline 2011-12 & 738 & 12.62 \\
\hline \multicolumn{3}{|l|}{ Moved in the last 5 years (adults): } \\
\hline 2005-06 & 1,663 & 20.33 \\
\hline 2009-10 & 1,216 & 15.53 \\
\hline 2010-11 & 1,116 & 10.90 \\
\hline 2011-12 & 1,100 & 8.95 \\
\hline \multicolumn{3}{|l|}{ Attending school (children 6-15) } \\
\hline 2005-06 & 4,325 & 85.92 \\
\hline 2009-10 & 4,668 & 81.68 \\
\hline 2010-11 & 4,303 & 76.62 \\
\hline 2011-12 & 4,707 & 80.50 \\
\hline \multicolumn{3}{|l|}{ Completed Primary School (children 11-15) } \\
\hline $2005-06$ & 258 & 11.92 \\
\hline 2009-10 & 267 & 11.01 \\
\hline 2010-11 & 241 & 10.72 \\
\hline 2011-12 & 255 & 10.43 \\
\hline
\end{tabular}

Source: Authors' elaborations on UNPS data 
Table 3: Descriptive Statistics of our Sample Variables

\begin{tabular}{|c|c|c|c|c|}
\hline & \multicolumn{4}{|c|}{ Mean } \\
\hline & \multicolumn{4}{|c|}{ (St.Dev.) } \\
\hline & 2005-06 & 2009-10 & 2010-11 & 2011-12 \\
\hline \multicolumn{5}{|l|}{ Dependent variables: } \\
\hline \multirow[t]{2}{*}{ Average school attendance } & .534 & .482 & .306 & .331 \\
\hline & $(.286)$ & $(.265)$ & $(.218)$ & (.221) \\
\hline \multirow[t]{2}{*}{ Average elementary completion } & .124 & .211 & .222 & .127 \\
\hline & (.237) & $(.277)$ & $(.288)$ & $(.309)$ \\
\hline \multirow[t]{2}{*}{ Rate of Idle children } & .008 & .014 & .008 & .005 \\
\hline & $(.070)$ & $(.090)$ & $(.067)$ & $(.050)$ \\
\hline \multicolumn{5}{|l|}{ Mobility variables: } \\
\hline \multirow[t]{2}{*}{ Child has moved } & .095 & .186 & .189 & .134 \\
\hline & (.293) & $(.389)$ & (.392) & $(.341)$ \\
\hline \multirow[t]{2}{*}{ Adult has moved } & .285 & .235 & .227 & .197 \\
\hline & $(.452)$ & $(.424)$ & $(.419)$ & $(.398)$ \\
\hline \multirow[t]{2}{*}{ Child is absent } & .099 & .172 & .261 & .335 \\
\hline & (.299) & $(.377)$ & $(.439)$ & $(.472)$ \\
\hline \multirow[t]{2}{*}{ Adult is absent } & .191 & .351 & .585 & .731 \\
\hline & (.392) & $(.477)$ & (.492) & $(.444)$ \\
\hline \multirow[t]{2}{*}{ Child left for education } & .024 & .038 & .044 & .035 \\
\hline & $(.154)$ & $(.191)$ & $(.206)$ & $(.183)$ \\
\hline \multirow[t]{2}{*}{ Child left to work } & .007 & .006 & .005 & .002 \\
\hline & (.082) & $(.075)$ & $(.069)$ & $(.046)$ \\
\hline
\end{tabular}




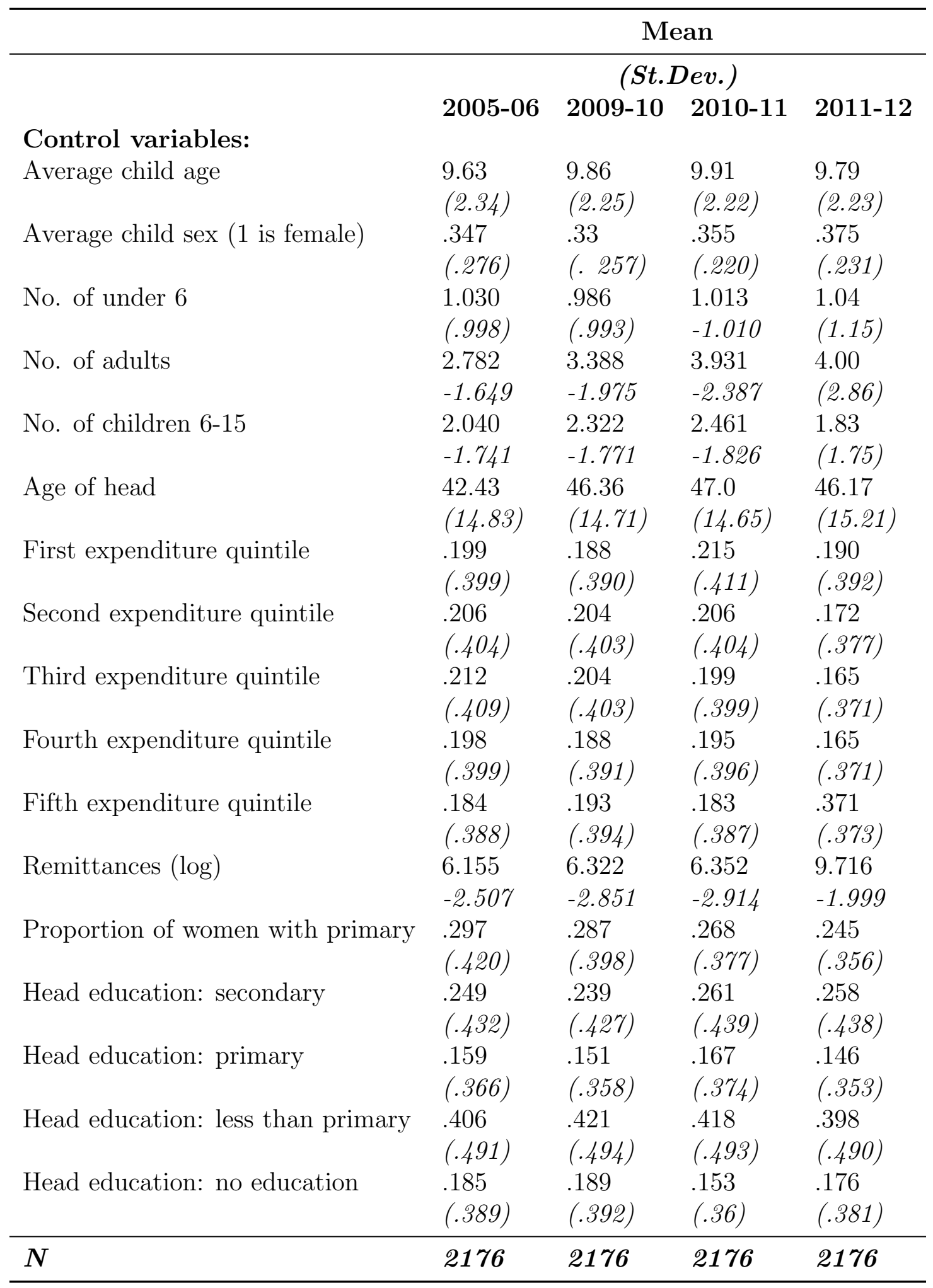


Table 4: Means of Variables for Migrant and Non-Migrant Households

\begin{tabular}{|c|c|c|}
\hline & Non-Migrant $\mathbf{H H}$ & Migrant $\mathbf{H H}$ \\
\hline \multicolumn{3}{|l|}{ Average Schooling } \\
\hline 2005 & 0.5423 & 0.5256 \\
\hline 2009 & 0.4990 & $0.4711^{*}$ \\
\hline 2010 & 0.3394 & $0.2961 * * *$ \\
\hline 2011 & 0.3743 & $0.3211^{* * *}$ \\
\hline \multicolumn{3}{|c|}{ Average Primary completion } \\
\hline 2005 & 0.0972 & 0.1080 \\
\hline 2009 & 0.0947 & $0.0784^{*}$ \\
\hline 2010 & 0.1101 & $0.0710^{* * *}$ \\
\hline 2011 & .0433 & $0.1446^{* * *}$ \\
\hline \multicolumn{3}{|c|}{ Proportion of Idle Children } \\
\hline 2005 & 0.1723 & $0.1410^{*}$ \\
\hline 2009 & 0.2343 & $0.1753^{* * *}$ \\
\hline 2010 & 0.2823 & 0.2560 \\
\hline 2011 & 0.0040 & 0.0055 \\
\hline \multicolumn{3}{|l|}{ Average child age } \\
\hline 2005 & 9.33 & $9.96^{* * *}$ \\
\hline 2009 & 9.54 & $10.06^{* * *}$ \\
\hline 2010 & 9.40 & $10.07^{* * *}$ \\
\hline 2011 & 9.27 & $9.91^{* * *}$ \\
\hline \multicolumn{3}{|l|}{ Average female } \\
\hline 2005 & 0.3431 & 0.3517 \\
\hline 2009 & 0.3202 & 0.3359 \\
\hline 2010 & 0.3573 & 0.3542 \\
\hline 2011 & 0.3661 & 0.3774 \\
\hline \multicolumn{3}{|c|}{ Number of children $0-5$} \\
\hline 2005 & 1.03 & 1.03 \\
\hline 2009 & 1.01 & 0.96 \\
\hline 2010 & 1.02 & 1.01 \\
\hline 2011 & 1.29 & $0.99^{* * *}$ \\
\hline \multicolumn{3}{|l|}{ Number of adults } \\
\hline 2005 & 2.42 & $3.18^{* * *}$ \\
\hline 2009 & 2.67 & $3.86^{* * *}$ \\
\hline 2010 & 2.41 & $4.45^{* * *}$ \\
\hline 2011 & 2.42 & $4.33^{* * *}$ \\
\hline \multicolumn{3}{|c|}{ Number of children $6-15$} \\
\hline 2005 & 1.95 & $2.15^{* *}$ \\
\hline 2009 & 2.11 & $2.46^{* * *}$ \\
\hline 2010 & 2.15 & $2.57^{* * *}$ \\
\hline 2011 & 1.82 & 1.84 \\
\hline \multicolumn{3}{|c|}{ Average age of head of $\mathrm{HH}$} \\
\hline 2005 & 42.76 & 42.07 \\
\hline 2009 & 45.24 & $47.10^{* *}$ \\
\hline 2010 & 44.87 & $47.72^{* * *}$ \\
\hline 2011 & 42.51 & $47.41^{* * *}$ \\
\hline
\end{tabular}

Significance level: $.1+.05^{*} .01^{* *} .001^{* * *}$ 
Proportion of Women with primary ed.

2005
2009
2010
2011
2005
2009
2010
2011

First expenditure quintile

Remittances log

2005
2009
2010

Second expenditure quintile

2009

2010

2011

Third expenditure quintile

2005
2009
2010
2011

Fourth expenditure quintile

2005
2009
2010
2011

Fifth expenditure quintile

0.2440

0.2355

0.2229

0.2102

5.84

5.71

5.56

9.47

0.2339

0.2488

0.2586

0.2224

0.2365

0.2477

0.2658

0.2543

0.2200

0.2281

0.2061

0.1860

0.1913

0.1613

0.1537

0.1632

0.1183

0.1060

0.1139

0.1290

0.2197

0.2222

0.1938

0.1865

0.4459

0.4507

0.4483

0.7647

0.1433

0.1485

0.1724

0.3283

$0.1903 \quad 0.3190 * * *$

$0.17960 .2823^{* * *}$

$0.1856 \quad 0.2885 * * *$

0.1746
$0.3540^{* * *}$

$0.3204 * * *$

$0.2828^{* *}$

$0.2530^{*}$

$6.88^{* * *}$

$7.29 * * *$

$7.17^{* * *}$

$9.80^{* * *}$

$0.1608^{* * *}$

$0.1468 * * *$

$0.1996 * *$

$0.1806^{*}$

$0.1715^{* * *}$

$0.1751^{* * *}$

$0.1855 * * *$

$0.1543^{* * *}$

0.2027

$0.1873^{*}$

0.1959

0.1603

0.2057

0.2064 **

$0.2089^{* *}$

0.1651

$0.2583^{* * *}$

$0.2500^{* * *}$

$0.2064 * * *$

$0.1750^{*}$

$0.1442^{* * *}$

$0.1652^{* * * *}$

$0.1380^{* *}$

0.1745

$0.3591 * * *$

$0.4002^{*}$

$0.4073+$

$0.7987+$

$0.1777^{*}$

0.1524

0.1662

$0.4257^{* * *}$

$0.2885^{* * *}$

Significance level: $.1+.05^{*} .01^{* *} .001^{* * *}$ 
Table 5: School attendance rate of children aged 6 to 15 in the household - linear probability model

\begin{tabular}{|c|c|c|c|}
\hline & $\mathrm{A}$ & B & $\mathrm{C}$ \\
\hline Child has moved & $\begin{array}{l}0.0303^{* *} \\
(0.00939)\end{array}$ & $\begin{array}{l}0.0301^{* *} \\
(0.00938)\end{array}$ & \\
\hline Adult has moved & $\begin{array}{l}-0.0136 \\
(0.00898)\end{array}$ & $\begin{array}{l}-0.0145 \\
(0.00896)\end{array}$ & $\begin{array}{l}-0.00715 \\
(0.00850)\end{array}$ \\
\hline Child is absent & & $\begin{array}{l}0.0156^{*} \\
(0.00712)\end{array}$ & $\begin{array}{l}0.0157^{*} \\
(0.00715)\end{array}$ \\
\hline Adult is absent & & $\begin{array}{c}-0.0213^{* *} \\
(0.00754)\end{array}$ & $\begin{array}{l}-0.0212^{* *} \\
(0.00754)\end{array}$ \\
\hline Child has moved for educ. & & & $\begin{array}{l}0.0324^{*} \\
(0.0152)\end{array}$ \\
\hline Child has moved to work & & & $\begin{array}{l}0.00368 \\
(0.0296)\end{array}$ \\
\hline Child age & $\begin{array}{l}0.124 * * * \\
(0.0184)\end{array}$ & $\begin{array}{l}0.124^{* * *} \\
(0.0184)\end{array}$ & $\begin{array}{l}0.126^{* * *} \\
(0.0184)\end{array}$ \\
\hline Child age sq. & $\begin{array}{l}-0.00554^{* * *} \\
(0.000898)\end{array}$ & $\begin{array}{l}-0.00554^{* * *} \\
(0.000899)\end{array}$ & $\begin{array}{l}-0.00563^{* * *} \\
(0.000899)\end{array}$ \\
\hline Gender & $\begin{array}{l}0.0451 \\
(0.0282)\end{array}$ & $\begin{array}{l}0.0468+ \\
(0.0282)\end{array}$ & $\begin{array}{l}0.0475+ \\
(0.0283)\end{array}$ \\
\hline Head ed. low & $\begin{array}{l}-0.00525 \\
(0.00803)\end{array}$ & $\begin{array}{c}-0.00597 \\
(0.00802)\end{array}$ & $\begin{array}{l}-0.00591 \\
(0.00802)\end{array}$ \\
\hline Head ed. primary & $\begin{array}{l}-0.0119 \\
(0.00871)\end{array}$ & $\begin{array}{l}-0.0123 \\
(0.00870)\end{array}$ & $\begin{array}{l}-0.0120 \\
(0.00873)\end{array}$ \\
\hline Head ed. secondary & $\begin{array}{l}-0.0138 \\
(0.0153)\end{array}$ & $\begin{array}{l}-0.0136 \\
(0.0152)\end{array}$ & $\begin{array}{l}-0.0127 \\
(0.0152)\end{array}$ \\
\hline Av. women with primary ed. & $\begin{array}{l}0.0567^{* * *} \\
(0.0147)\end{array}$ & $\begin{array}{l}0.0549^{* * *} \\
(0.0148)\end{array}$ & $\begin{array}{l}0.0530 * * * \\
(0.0148)\end{array}$ \\
\hline No. of children $0-5$ & $\begin{array}{l}0.00167 \\
(0.00445)\end{array}$ & $\begin{array}{l}0.00119 \\
(0.00443)\end{array}$ & $\begin{array}{l}0.00132 \\
(0.00445)\end{array}$ \\
\hline No. of children 6-15 & $\begin{array}{l}-0.0793 * * * \\
(0.00405)\end{array}$ & $\begin{array}{l}-0.0799^{* * *} \\
(0.00407)\end{array}$ & $\begin{array}{l}-0.0791 * * * \\
(0.00405)\end{array}$ \\
\hline No. of adults & $\begin{array}{l}-0.0197^{* * *} \\
(0.00262)\end{array}$ & $\begin{array}{l}-0.0181^{* * *} \\
(0.00264)\end{array}$ & $\begin{array}{l}-0.0182^{* * *} \\
(0.00264)\end{array}$ \\
\hline 2nd Expenditure quint. & $\begin{array}{l}0.0123 \\
(0.0103)\end{array}$ & $\begin{array}{l}0.0112 \\
(0.0103)\end{array}$ & $\begin{array}{l}0.0103 \\
(0.0103)\end{array}$ \\
\hline 3rd Expenditure quint. & $\begin{array}{l}0.00946 \\
(0.0109)\end{array}$ & $\begin{array}{l}0.00912 \\
(0.0109)\end{array}$ & $\begin{array}{l}0.00837 \\
(0.0109)\end{array}$ \\
\hline 4th Expenditure quint. & $\begin{array}{l}0.0336^{* *} \\
(0.0119)\end{array}$ & $\begin{array}{l}0.0332 * * \\
(0.0119)\end{array}$ & $\begin{array}{l}0.0320^{* *} \\
(0.0119)\end{array}$ \\
\hline 5th Expenditure quint. & $\begin{array}{l}0.0136 \\
(0.0138)\end{array}$ & $\begin{array}{l}0.0133 \\
(0.0138)\end{array}$ & $\begin{array}{l}0.0120 \\
(0.0138)\end{array}$ \\
\hline Log of remittances & $\begin{array}{l}0.000572 \\
(0.00265)\end{array}$ & $\begin{array}{l}0.000276 \\
(0.00264)\end{array}$ & $\begin{array}{l}0.000250 \\
(0.00265)\end{array}$ \\
\hline $2009-10$ & $\begin{array}{l}-0.0314^{* * *} \\
(0.00863)\end{array}$ & $\begin{array}{l}-0.0296 * * * \\
(0.00875)\end{array}$ & $\begin{array}{l}-0.0268^{* *} \\
(0.00871)\end{array}$ \\
\hline 2010-11 & $\begin{array}{c}-0.182^{* * *} \\
(0.00916)\end{array}$ & $\begin{array}{c}-0.178^{* * *} \\
(0.00970)\end{array}$ & $\begin{array}{l}-0.176^{* * *} \\
(0.00967)\end{array}$ \\
\hline 2011-12 & $\begin{array}{l}-0.174^{* * *} \\
(0.0280)\end{array}$ & $\begin{array}{l}-0.165 * * * \\
(0.0281)\end{array}$ & $\begin{array}{l}-0.163^{* * *} \\
(0.0281)\end{array}$ \\
\hline Constant & $\begin{array}{l}0.106 \\
(0.0907)\end{array}$ & $\begin{array}{l}0.110 \\
(0.0907)\end{array}$ & $\begin{array}{l}0.101 \\
(0.0908)\end{array}$ \\
\hline Observations & 7217 & 7217 & 7217 \\
\hline$R 2$ & 0.303 & 0.305 & 0.304 \\
\hline Adjusted R2 & 0.301 & 0.303 & 0.301 \\
\hline
\end{tabular}


Table 6: School attendance rate of children aged 6 to 15 in the household - two-side censoring model

\begin{tabular}{|c|c|c|c|}
\hline & A & B & $\mathrm{C}$ \\
\hline Child has moved & $\begin{array}{l}0.0359^{* * *} \\
(0.0106)\end{array}$ & $\begin{array}{l}0.0358^{* * *} \\
(0.0105)\end{array}$ & \\
\hline Adult has moved & $\begin{array}{l}-0.0157 \\
(0.0100)\end{array}$ & $\begin{array}{c}-0.0169+ \\
(0.00996)\end{array}$ & $\begin{array}{l}-0.00790 \\
(0.00939)\end{array}$ \\
\hline Child is absent & & $\begin{array}{l}0.0240^{* *} \\
(0.00809)\end{array}$ & $\begin{array}{l}0.0239^{* *} \\
(0.00813)\end{array}$ \\
\hline Adult is absent & & $\begin{array}{c}-0.0235^{* *} \\
(0.00867)\end{array}$ & $\begin{array}{l}-0.0237^{* *} \\
(0.00868)\end{array}$ \\
\hline Child has moved for educ. & & & $\begin{array}{l}0.0376^{*} \\
(0.0170)\end{array}$ \\
\hline Child has moved to work & & & $\begin{array}{c}-0.00439 \\
(0.0364)\end{array}$ \\
\hline Child age & $\begin{array}{l}0.138^{* * *} \\
(0.0239)\end{array}$ & $\begin{array}{l}0.138^{* * *} \\
(0.0240)\end{array}$ & $\begin{array}{l}0.140^{* * *} \\
(0.0242)\end{array}$ \\
\hline Child age sq. & $\begin{array}{l}-0.00608^{* * *} \\
(0.00116)\end{array}$ & $\begin{array}{l}-0.00609^{* * *} \\
(0.00116)\end{array}$ & $\begin{array}{l}-0.00618^{* * *} \\
(0.00117)\end{array}$ \\
\hline Gender & $\begin{array}{l}0.0697+ \\
(0.0356)\end{array}$ & $\begin{array}{l}0.0724^{*} \\
(0.0355)\end{array}$ & $\begin{array}{l}0.0733^{*} \\
(0.0357)\end{array}$ \\
\hline Head ed. low & $\begin{array}{l}-0.00253 \\
(0.00925)\end{array}$ & $\begin{array}{l}-0.00332 \\
(0.00919)\end{array}$ & $\begin{array}{l}-0.00343 \\
(0.00921)\end{array}$ \\
\hline Head ed. primary & $\begin{array}{l}-0.00642 \\
(0.00977)\end{array}$ & $\begin{array}{l}-0.00701 \\
(0.00971)\end{array}$ & $\begin{array}{l}-0.00628 \\
(0.00976)\end{array}$ \\
\hline Head ed. secondary & $\begin{array}{l}-0.0113 \\
(0.0168)\end{array}$ & $\begin{array}{l}-0.0112 \\
(0.0168)\end{array}$ & $\begin{array}{l}-0.00937 \\
(0.0168)\end{array}$ \\
\hline Av. women with primary ed. & $\begin{array}{l}0.0719^{* * *} \\
(0.0161)\end{array}$ & $\begin{array}{l}0.0701^{* * *} \\
(0.0160)\end{array}$ & $\begin{array}{l}0.0678^{* * *} \\
(0.0161)\end{array}$ \\
\hline No. of children 0-5 & $\begin{array}{l}-0.00255 \\
(0.00502)\end{array}$ & $\begin{array}{l}-0.00300 \\
(0.00502)\end{array}$ & $\begin{array}{l}-0.00288 \\
(0.00502)\end{array}$ \\
\hline No. of children 6-15 & $\begin{array}{l}-0.0957^{* * *} \\
(0.00516)\end{array}$ & $\begin{array}{l}-0.0969 * * * \\
(0.00523)\end{array}$ & $\begin{array}{l}-0.0956^{* * *} \\
(0.00520)\end{array}$ \\
\hline No. of adults & $\begin{array}{l}-0.0226^{* * *} \\
(0.00324)\end{array}$ & $\begin{array}{l}-0.0208 * * * \\
(0.00327)\end{array}$ & $\begin{array}{l}-0.0208 * * * \\
(0.00330)\end{array}$ \\
\hline 2nd Expenditure quint. & $\begin{array}{l}0.00708 \\
(0.0120)\end{array}$ & $\begin{array}{l}0.00611 \\
(0.0120)\end{array}$ & $\begin{array}{l}0.00520 \\
(0.0119)\end{array}$ \\
\hline 3rd Expenditure quint. & $\begin{array}{l}0.000705 \\
(0.0128)\end{array}$ & $\begin{array}{l}0.000822 \\
(0.0127)\end{array}$ & $\begin{array}{l}-0.000162 \\
(0.0127)\end{array}$ \\
\hline 4th Expenditure quint. & $\begin{array}{l}0.0288^{*} \\
(0.0136)\end{array}$ & $\begin{array}{l}0.0290^{*} \\
(0.0135)\end{array}$ & $\begin{array}{l}0.0277^{*} \\
(0.0135)\end{array}$ \\
\hline 5th Expenditure quint. & $\begin{array}{l}0.00382 \\
(0.0157)\end{array}$ & $\begin{array}{l}0.00416 \\
(0.0155)\end{array}$ & $\begin{array}{l}0.00245 \\
(0.0156)\end{array}$ \\
\hline Log of remittances & $\begin{array}{l}0.000302 \\
(0.00132)\end{array}$ & $\begin{array}{l}0.000236 \\
(0.00132)\end{array}$ & $\begin{array}{l}0.000427 \\
(0.00132)\end{array}$ \\
\hline 2009 & $\begin{array}{l}-0.0420^{* * *} \\
(0.00947)\end{array}$ & $\begin{array}{l}-0.0407^{* * *} \\
(0.00957)\end{array}$ & $\begin{array}{l}-0.0374^{* * * *} \\
(0.00958)\end{array}$ \\
\hline 2010 & $\begin{array}{l}-0.219^{* * *} \\
(0.0103)\end{array}$ & $\begin{array}{l}-0.215^{* * *} \\
(0.0110)\end{array}$ & $\begin{array}{l}-0.213^{* * *} \\
(0.0110)\end{array}$ \\
\hline 2011 & $\begin{array}{l}-0.207^{* * *} \\
(0.0135)\end{array}$ & $\begin{array}{l}-0.201^{* * *} \\
(0.0139)\end{array}$ & $\begin{array}{l}-0.200^{* * *} \\
(0.0139)\end{array}$ \\
\hline Observations & 7217 & 7217 & 7217 \\
\hline
\end{tabular}

Significance level: $.1+.05^{*} \cdot 01^{* *} .001^{* * *}$. Robust S.E. in parenthesis. 
Table 7: Primary school completion rate of children aged 11 to 15 in the household - linear probability model

\begin{tabular}{|c|c|c|c|}
\hline & $\mathrm{A}$ & B & $\mathrm{C}$ \\
\hline Child has moved & $\begin{array}{l}0.0161 \\
(0.0122)\end{array}$ & $\begin{array}{l}0.0163 \\
(0.0132)\end{array}$ & \\
\hline Adult has moved & $\begin{array}{l}0.00624 \\
(0.0118)\end{array}$ & $\begin{array}{c}0.00578 \\
(0.0128)\end{array}$ & $\begin{array}{l}0.0103 \\
(0.0123)\end{array}$ \\
\hline Child is absent & & $\begin{array}{l}0.0268^{*} \\
(0.0106)\end{array}$ & $\begin{array}{l}0.0267^{*} \\
(0.0106)\end{array}$ \\
\hline Adult is absent & & $\begin{array}{l}-0.000320 \\
(0.0105)\end{array}$ & $\begin{array}{l}-0.000226 \\
(0.0105)\end{array}$ \\
\hline Child has moved for educ. & & & $\begin{array}{l}0.00911 \\
(0.0232)\end{array}$ \\
\hline Child has moved to work & & & $\begin{array}{l}0.0490 \\
(0.0972)\end{array}$ \\
\hline Child age & $\begin{array}{c}-0.0518 \\
(0.0323)\end{array}$ & $\begin{array}{l}-0.0545 \\
(0.0364)\end{array}$ & $\begin{array}{l}-0.0538 \\
(0.0364)\end{array}$ \\
\hline Child age sq. & $\begin{array}{l}0.00281+ \\
(0.00146)\end{array}$ & $\begin{array}{c}0.00292+ \\
(0.00168)\end{array}$ & $\begin{array}{l}0.00288+ \\
(0.00168)\end{array}$ \\
\hline Gender & $\begin{array}{l}0.00289 \\
(0.0297)\end{array}$ & $\begin{array}{c}0.00702 \\
(0.0355)\end{array}$ & $\begin{array}{l}0.00674 \\
(0.0355)\end{array}$ \\
\hline Head ed. low & $\begin{array}{l}-0.0180 \\
(0.0114)\end{array}$ & $\begin{array}{c}-0.0181 \\
(0.0119)\end{array}$ & $\begin{array}{c}-0.0184 \\
(0.0119)\end{array}$ \\
\hline Head ed. primary & $\begin{array}{l}0.00605 \\
(0.0130)\end{array}$ & $\begin{array}{l}0.00572 \\
(0.0166)\end{array}$ & $\begin{array}{l}0.00582 \\
(0.0166)\end{array}$ \\
\hline Head ed. secondary & $\begin{array}{l}0.0184 \\
(0.0195)\end{array}$ & $\begin{array}{l}0.0184 \\
(0.0236)\end{array}$ & $\begin{array}{l}0.0180 \\
(0.0236)\end{array}$ \\
\hline Av. women with primary ed. & $\begin{array}{l}0.108^{* * *} \\
(0.0193)\end{array}$ & $\begin{array}{l}0.107^{* * *} \\
(0.0230)\end{array}$ & $\begin{array}{l}0.106^{* * *} \\
(0.0230)\end{array}$ \\
\hline No. of children $0-5$ & $\begin{array}{l}-0.00437 \\
(0.00592)\end{array}$ & $\begin{array}{l}-0.00491 \\
(0.00539)\end{array}$ & $\begin{array}{l}-0.00509 \\
(0.00540)\end{array}$ \\
\hline No. of children $6-15$ & $\begin{array}{l}-0.0156^{* * *} \\
(0.00464)\end{array}$ & $\begin{array}{c}-0.0169^{* * *} \\
(0.00463)\end{array}$ & $\begin{array}{l}-0.0165^{* * *} \\
(0.00461)\end{array}$ \\
\hline No. of adults & $\begin{array}{l}0.00508 \\
(0.00344)\end{array}$ & $\begin{array}{l}0.00517 \\
(0.00369)\end{array}$ & $\begin{array}{l}0.00519 \\
(0.00368)\end{array}$ \\
\hline 2nd Expenditure quint. & $\begin{array}{c}-0.00325 \\
(0.0133)\end{array}$ & $\begin{array}{l}-0.00268 \\
(0.0106)\end{array}$ & $\begin{array}{l}-0.00315 \\
(0.0106)\end{array}$ \\
\hline 3rd Expenditure quint. & $\begin{array}{l}0.0119 \\
(0.0142)\end{array}$ & $\begin{array}{l}0.0129 \\
(0.0123)\end{array}$ & $\begin{array}{l}0.0122 \\
(0.0123)\end{array}$ \\
\hline 4th Expenditure quint. & $\begin{array}{l}0.00730 \\
(0.0156)\end{array}$ & $\begin{array}{c}0.00794 \\
(0.0143)\end{array}$ & $\begin{array}{l}0.00709 \\
(0.0142)\end{array}$ \\
\hline 5th Expenditure quint. & $\begin{array}{c}0.0327+ \\
(0.0184)\end{array}$ & $\begin{array}{c}0.0331+ \\
(0.0190)\end{array}$ & $\begin{array}{c}0.0320+ \\
(0.0189)\end{array}$ \\
\hline Log of remittances & $\begin{array}{l}-0.00255 \\
(0.00388)\end{array}$ & $\begin{array}{l}-0.00253 \\
(0.00520)\end{array}$ & $\begin{array}{l}-0.00246 \\
(0.00520)\end{array}$ \\
\hline 2009 & $\begin{array}{l}0.104^{* * *} \\
(0.0109)\end{array}$ & $\begin{array}{l}0.101^{* * *} \\
(0.0104)\end{array}$ & $\begin{array}{l}0.103^{* * *} \\
(0.0105)\end{array}$ \\
\hline 2010 & $\begin{array}{l}0.128^{* * *} \\
(0.0119)\end{array}$ & $\begin{array}{l}0.122^{* * *} \\
(0.0125)\end{array}$ & $\begin{array}{l}0.123^{* * *} \\
(0.0125)\end{array}$ \\
\hline 2011 & $\begin{array}{l}0.0688+ \\
(0.0412)\end{array}$ & $\begin{array}{l}0.0627 \\
(0.0520)\end{array}$ & $\begin{array}{l}0.0627 \\
(0.0519)\end{array}$ \\
\hline Constant & $\begin{array}{l}0.316+ \\
(0.177)\end{array}$ & $\begin{array}{l}0.332+ \\
(0.197)\end{array}$ & $\begin{array}{l}0.329+ \\
(0.197)\end{array}$ \\
\hline Observations & 4855 & 4855 & 4855 \\
\hline $\mathrm{R} 2$ & 0.100 & 0.103 & 0.102 \\
\hline Adjusted R2 & -0.461 & 0.099 & 0.098 \\
\hline
\end{tabular}


Table 8: Primary school completion rate of children aged 11 to 15 in the household - two-side censoring model

\begin{tabular}{|c|c|c|c|}
\hline & A & B & $\mathrm{C}$ \\
\hline Child has moved & $\begin{array}{l}0.0299 \\
(0.0310)\end{array}$ & $\begin{array}{l}0.0315 \\
(0.0306)\end{array}$ & \\
\hline Adult has moved & $\begin{array}{l}0.0333 \\
(0.0303)\end{array}$ & $\begin{array}{l}0.0345 \\
(0.0297)\end{array}$ & $\begin{array}{l}0.0412 \\
(0.0295)\end{array}$ \\
\hline Child is absent & & $\begin{array}{l}0.0514^{*} \\
(0.0247)\end{array}$ & $\begin{array}{l}0.0523^{*} \\
(0.0248)\end{array}$ \\
\hline Adult is absent & & $\begin{array}{l}0.0102 \\
(0.0258)\end{array}$ & $\begin{array}{l}0.00967 \\
(0.0262)\end{array}$ \\
\hline Child has moved for educ. & & & $\begin{array}{l}0.00210 \\
(0.0515)\end{array}$ \\
\hline Child has moved to work & & & $\begin{array}{l}0.135 \\
(0.147)\end{array}$ \\
\hline Child age & $\begin{array}{l}-0.0821 \\
(0.0911)\end{array}$ & $\begin{array}{l}-0.0950 \\
(0.0916)\end{array}$ & $\begin{array}{l}-0.0915 \\
(0.0926)\end{array}$ \\
\hline Child age sq. & $\begin{array}{l}0.00446 \\
(0.00413)\end{array}$ & $\begin{array}{l}0.00501 \\
(0.00414)\end{array}$ & $\begin{array}{l}0.00484 \\
(0.00417)\end{array}$ \\
\hline Gender & $\begin{array}{l}-0.00271 \\
(0.0909)\end{array}$ & $\begin{array}{l}0.000417 \\
(0.0926)\end{array}$ & $\begin{array}{l}0.00200 \\
(0.0946)\end{array}$ \\
\hline Head ed. low & $\begin{array}{l}0.00317 \\
(0.0383)\end{array}$ & $\begin{array}{l}0.00392 \\
(0.0389)\end{array}$ & $\begin{array}{l}0.00421 \\
(0.0386)\end{array}$ \\
\hline Head ed. primary & $\begin{array}{l}0.0549 \\
(0.0383)\end{array}$ & $\begin{array}{l}0.0548 \\
(0.0377)\end{array}$ & $\begin{array}{l}0.0565 \\
(0.0382)\end{array}$ \\
\hline Head ed. secondary & $\begin{array}{l}0.0587 \\
(0.0480)\end{array}$ & $\begin{array}{l}0.0605 \\
(0.0476)\end{array}$ & $\begin{array}{l}0.0586 \\
(0.0483)\end{array}$ \\
\hline Av. women with primary ed. & $\begin{array}{l}0.214^{* * *} \\
(0.0493)\end{array}$ & $\begin{array}{l}0.210^{* * *} \\
(0.0506)\end{array}$ & $\begin{array}{l}0.211^{* * *} \\
(0.0510)\end{array}$ \\
\hline No. of children 0-5 & $\begin{array}{l}-0.0134 \\
(0.0144)\end{array}$ & $\begin{array}{l}-0.0139 \\
(0.0146)\end{array}$ & $\begin{array}{l}-0.0146 \\
(0.0147)\end{array}$ \\
\hline No. of children $6-15$ & $\begin{array}{l}-0.0420^{* * *} \\
(0.0126)\end{array}$ & $\begin{array}{l}-0.0456^{* * *} \\
(0.0127)\end{array}$ & $\begin{array}{l}-0.0442^{* * *} \\
(0.0128)\end{array}$ \\
\hline No. of adults & $\begin{array}{l}0.00960 \\
(0.00928)\end{array}$ & $\begin{array}{l}0.00889 \\
(0.00938)\end{array}$ & $\begin{array}{l}0.00907 \\
(0.00924)\end{array}$ \\
\hline 2nd Expenditure quint. & $\begin{array}{l}-0.0155 \\
(0.0392)\end{array}$ & $\begin{array}{l}-0.0102 \\
(0.0395)\end{array}$ & $\begin{array}{l}-0.0117 \\
(0.0400)\end{array}$ \\
\hline 3rd Expenditure quint. & $\begin{array}{l}0.0281 \\
(0.0404)\end{array}$ & $\begin{array}{l}0.0357 \\
(0.0409)\end{array}$ & $\begin{array}{l}0.0334 \\
(0.0413)\end{array}$ \\
\hline 4th Expenditure quint. & $\begin{array}{l}0.0316 \\
(0.0392)\end{array}$ & $\begin{array}{l}0.0368 \\
(0.0391)\end{array}$ & $\begin{array}{l}0.0355 \\
(0.0399)\end{array}$ \\
\hline 5th Expenditure quint. & $\begin{array}{l}0.101^{*} \\
(0.0443)\end{array}$ & $\begin{array}{l}0.104^{*} \\
(0.0445)\end{array}$ & $\begin{array}{l}0.102^{*} \\
(0.0447)\end{array}$ \\
\hline Log of Remittances & $\begin{array}{l}-0.00295 \\
(0.00349)\end{array}$ & $\begin{array}{l}-0.00264 \\
(0.00356)\end{array}$ & $\begin{array}{l}-0.00261 \\
(0.00356)\end{array}$ \\
\hline 2009 & $\begin{array}{l}0.254^{* * *} \\
(0.0260)\end{array}$ & $\begin{array}{l}0.248^{* * *} \\
(0.0260)\end{array}$ & $\begin{array}{l}0.252^{* * *} \\
(0.0265)\end{array}$ \\
\hline 2010 & $\begin{array}{l}0.322^{* * *} \\
(0.0310)\end{array}$ & $\begin{array}{l}0.305^{* * *} \\
(0.0327)\end{array}$ & $\begin{array}{l}0.309^{* * *} \\
(0.0329)\end{array}$ \\
\hline 2011 & $\begin{array}{l}0.0947 \\
(0.0594)\end{array}$ & $\begin{array}{l}0.0785 \\
(0.0611)\end{array}$ & $\begin{array}{l}0.0822 \\
(0.0614)\end{array}$ \\
\hline Observations & 4855 & 4855 & 4855 \\
\hline
\end{tabular}


Table 9: School attendance rate of children in the household by age groups - Linear Probability model

\begin{tabular}{|c|c|c|c|}
\hline Children 6 to 10 & A & B & C \\
\hline Child has moved & $\begin{array}{l}0.0106 \\
(-0.0075)\end{array}$ & $\begin{array}{l}0.01 \\
(-0.0075)\end{array}$ & \\
\hline Adullt has moved & $\begin{array}{c}-0.0046 \\
(-0.0068)\end{array}$ & $\begin{array}{c}-0.00053 \\
(-0.0068)\end{array}$ & $\begin{array}{c}-0.0032 \\
(-0.0066)\end{array}$ \\
\hline Child is absent & & $\begin{array}{l}0.01533^{*} \\
(-0.0057)\end{array}$ & $\begin{array}{l}0.01522^{*} \\
(-0.0057)\end{array}$ \\
\hline Adult is absent & & $\begin{array}{l}-0.01977^{*} \\
(-0.006)\end{array}$ & $\begin{array}{l}-0.0199^{*} * * \\
(-0.006)\end{array}$ \\
\hline Child has moved for educ. & & & $\begin{array}{l}0.0223+ \\
(-0.0122)\end{array}$ \\
\hline Child has moved to work & & & $\begin{array}{l}-0.0542 \\
(-0.044)\end{array}$ \\
\hline Children 11 to 15 & A & B & C \\
\hline Child has moved & $\begin{array}{c}0.01888^{*} \\
(-0.0068)\end{array}$ & $\begin{array}{c}0.01188 \text { * } \\
(-0.0068)\end{array}$ & \\
\hline Adult has moved & $\begin{array}{c}-0.0087 \\
\left(-0.0066^{\circ}\right)\end{array}$ & $\begin{array}{c}-0.0093 \\
(-0.0060)\end{array}$ & $\begin{array}{c}-0.0043 \\
(-0.0063)\end{array}$ \\
\hline Child is absent & & $\begin{array}{c}-0.0016 \\
(-0.00022)\end{array}$ & $\begin{array}{c}-0.0016 \\
(-0.00322)\end{array}$ \\
\hline Adult is absent & & $\begin{array}{c}-0.0154^{*} \\
(-0.0059)\end{array}$ & $\begin{array}{l}-0.0155^{3} * \\
(-0.00595)\end{array}$ \\
\hline Child has moved for educ. & & & $\begin{array}{c}0.0257^{7} \\
(-0.0112)\end{array}$ \\
\hline Child has moved to wolk & & & $\begin{array}{l}0.0401+ \\
(-0.0239)\end{array}$ \\
\hline
\end{tabular}

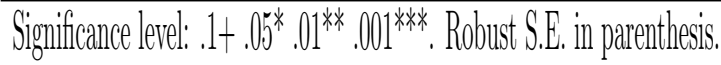


Table 10: Proportion of idle children aged 6 to 15 in the household - linear probability model

\begin{tabular}{|c|c|c|c|}
\hline & A & B & $\mathrm{C}$ \\
\hline Child has moved & $\begin{array}{l}-0.0420^{* * *} \\
(0.0104)\end{array}$ & $\begin{array}{l}-0.0419^{* * *} \\
(0.0104)\end{array}$ & \\
\hline Adult has moved & $\begin{array}{l}0.0204^{*} \\
(0.00961)\end{array}$ & $\begin{array}{l}0.0209^{*} \\
(0.00959)\end{array}$ & $\begin{array}{l}0.0106 \\
(0.00911)\end{array}$ \\
\hline Child is absent & & $\begin{array}{l}-0.0161^{*} \\
(0.00800)\end{array}$ & $\begin{array}{l}-0.0162^{*} \\
(0.00801)\end{array}$ \\
\hline Adult is absent & & $\begin{array}{l}0.0115 \\
(0.00875)\end{array}$ & $\begin{array}{l}0.0116 \\
(0.00875)\end{array}$ \\
\hline Child has moved for educ. & & & $\begin{array}{l}-0.0338^{*} \\
(0.0144)\end{array}$ \\
\hline Child has moved to work & & & $\begin{array}{l}0.00882 \\
(0.0394)\end{array}$ \\
\hline Child age & $\begin{array}{l}-0.217^{* * * *} \\
(0.0184)\end{array}$ & $\begin{array}{l}-0.217^{* * *} \\
(0.0184)\end{array}$ & $\begin{array}{l}-0.220^{* * *} \\
(0.0184)\end{array}$ \\
\hline Child age sq. & $\begin{array}{l}0.00956^{* * *} \\
(0.000892)\end{array}$ & $\begin{array}{l}0.00958^{* * *} \\
(0.000892)\end{array}$ & $\begin{array}{l}0.00970^{* * *} \\
(0.000893)\end{array}$ \\
\hline Gender & $\begin{array}{c}-0.00567 \\
(0.0233)\end{array}$ & $\begin{array}{c}-0.00691 \\
(0.0233)\end{array}$ & $\begin{array}{l}-0.00764 \\
(0.0234)\end{array}$ \\
\hline Head ed. low & $\begin{array}{l}0.0225^{* *} \\
(0.00871)\end{array}$ & $\begin{array}{l}0.0230^{* *} \\
(0.00870)\end{array}$ & $\begin{array}{l}0.0229^{* *} \\
(0.00872)\end{array}$ \\
\hline Head ed. primary & $\begin{array}{l}0.0393 * * * \\
(0.00957)\end{array}$ & $\begin{array}{l}0.0397 * * * \\
(0.00957)\end{array}$ & $\begin{array}{l}0.0392 * * * \\
(0.00960)\end{array}$ \\
\hline Head ed. secondary & $\begin{array}{l}0.0181 \\
(0.0153)\end{array}$ & $\begin{array}{l}0.0181 \\
(0.0153)\end{array}$ & $\begin{array}{l}0.0170 \\
(0.0152)\end{array}$ \\
\hline Av. women with primary ed. & $\begin{array}{l}-0.0326^{*} \\
(0.0144)\end{array}$ & $\begin{array}{l}-0.0313^{*} \\
(0.0144)\end{array}$ & $\begin{array}{l}-0.0290^{*} \\
(0.0143)\end{array}$ \\
\hline No. of children $0-5$ & $\begin{array}{l}-0.00718 \\
(0.00502)\end{array}$ & $\begin{array}{c}-0.00679 \\
(0.00502)\end{array}$ & $\begin{array}{l}-0.00697 \\
(0.00502)\end{array}$ \\
\hline No. of children $6-15$ & $\begin{array}{l}0.0331^{* * *} \\
(0.00357)\end{array}$ & $\begin{array}{l}0.0338^{* * * *} \\
(0.00360)\end{array}$ & $\begin{array}{l}0.0324^{* * * *} \\
(0.00360)\end{array}$ \\
\hline No. of adults & $\begin{array}{l}0.00244 \\
(0.00259)\end{array}$ & $\begin{array}{l}0.00156 \\
(0.00264)\end{array}$ & $\begin{array}{l}0.00165 \\
(0.00263)\end{array}$ \\
\hline 2nd Expenditure quint. & $\begin{array}{l}-0.0240^{*} \\
(0.0112)\end{array}$ & $\begin{array}{l}-0.0236^{*} \\
(0.0112)\end{array}$ & $\begin{array}{l}-0.0222^{*} \\
(0.0112)\end{array}$ \\
\hline 3rd Expenditure quint. & $\begin{array}{l}-0.0314^{* *} \\
(0.0121)\end{array}$ & $\begin{array}{l}-0.0314^{* *} \\
(0.0120)\end{array}$ & $\begin{array}{l}-0.0304^{*} \\
(0.0121)\end{array}$ \\
\hline 4th Expenditure quint. & $\begin{array}{l}-0.0646^{* * *} \\
(0.0134)\end{array}$ & $\begin{array}{l}-0.0644^{* * *} \\
(0.0133)\end{array}$ & $\begin{array}{l}-0.0628^{* * *} \\
(0.0133)\end{array}$ \\
\hline 5th Expenditure quint. & $\begin{array}{l}-0.0527^{* * *} \\
(0.0157)\end{array}$ & $\begin{array}{l}-0.0524^{* * *} \\
(0.0157)\end{array}$ & $\begin{array}{l}-0.0506^{* *} \\
(0.0157)\end{array}$ \\
\hline Log of remittances & $\begin{array}{l}0.00214 \\
(0.00252)\end{array}$ & $\begin{array}{l}0.00233 \\
(0.00252)\end{array}$ & $\begin{array}{l}0.00233 \\
(0.00253)\end{array}$ \\
\hline 2009 & $\begin{array}{l}0.0386^{* * *} \\
(0.00907)\end{array}$ & $\begin{array}{l}0.0383^{* * *} \\
(0.00920)\end{array}$ & $\begin{array}{c}0.0343^{* * *} \\
(0.00915)\end{array}$ \\
\hline 2010 & $\begin{array}{l}0.0763^{* * *} \\
(0.0104)\end{array}$ & $\begin{array}{l}0.0754^{* * *} \\
(0.0110)\end{array}$ & $\begin{array}{l}0.0722^{* * *} \\
(0.0109)\end{array}$ \\
\hline 2011 & $\begin{array}{l}-0.172^{* * *} \\
(0.0263)\end{array}$ & $\begin{array}{l}-0.176^{* * *} \\
(0.0267)\end{array}$ & $\begin{array}{l}-0.178^{* * *} \\
(0.0267)\end{array}$ \\
\hline Constant & $\begin{array}{l}1.249^{* * *} \\
(0.0915)\end{array}$ & $\begin{array}{l}1.247 * * * \\
(0.0916)\end{array}$ & $\begin{array}{l}1.261^{* * *} \\
(0.0916)\end{array}$ \\
\hline Observations & 7217 & 7217 & 7217 \\
\hline $\mathrm{R} 2$ & 0.227 & 0.227 & 0.225 \\
\hline Adjusted R2 & 0.224 & 0.225 & 0.223 \\
\hline
\end{tabular}

Significance level: .1+.05*.01**.001***. Robust S.E. in parenthesis. 
Table 11: Proportion of idle children aged 6 to 15 in the household - two-side censoring model

\begin{tabular}{|c|c|c|c|}
\hline & A & B & $\mathrm{C}$ \\
\hline Child has moved & $\begin{array}{l}-0.168^{* * *} \\
(0.0388)\end{array}$ & $\begin{array}{l}-0.166^{* * *} \\
(0.0381)\end{array}$ & \\
\hline Adult has moved & $\begin{array}{l}0.0629+ \\
(0.0329)\end{array}$ & $\begin{array}{l}0.0622+ \\
(0.0328)\end{array}$ & $\begin{array}{l}0.0156 \\
(0.0301)\end{array}$ \\
\hline Child is absent & & $\begin{array}{l}-0.0746^{* *} \\
(0.0255)\end{array}$ & $\begin{array}{c}-0.0771^{* *} \\
(0.0261)\end{array}$ \\
\hline Adult is absent & & $\begin{array}{l}0.0477+ \\
(0.0288)\end{array}$ & $\begin{array}{l}0.0492+ \\
(0.0296)\end{array}$ \\
\hline Child has moved for educ. & & & $\begin{array}{l}-0.168^{* *} \\
(0.0582)\end{array}$ \\
\hline Child has moved to work & & & $\begin{array}{l}-0.0386 \\
(0.0796)\end{array}$ \\
\hline Child age & $\begin{array}{l}-0.608^{* * *} \\
(0.0736)\end{array}$ & $\begin{array}{l}-0.612^{* * *} \\
(0.0728)\end{array}$ & $\begin{array}{l}-0.627^{* * *} \\
(0.0753)\end{array}$ \\
\hline Child age sq. & $\begin{array}{l}0.0260 * * * \\
(0.00398)\end{array}$ & $\begin{array}{l}0.0261^{* * *} \\
(0.00392)\end{array}$ & $\begin{array}{l}0.0269 * * * \\
(0.00407)\end{array}$ \\
\hline Gender & $\begin{array}{l}-0.0706 \\
(0.115)\end{array}$ & $\begin{array}{l}-0.0778 \\
(0.108)\end{array}$ & $\begin{array}{l}-0.0978 \\
(0.110)\end{array}$ \\
\hline Head ed. low & $\begin{array}{l}0.0111 \\
(0.0600)\end{array}$ & $\begin{array}{l}0.0139 \\
(0.0557)\end{array}$ & $\begin{array}{l}0.0147 \\
(0.0551)\end{array}$ \\
\hline Head ed. primary & $\begin{array}{l}0.0343 \\
(0.0797)\end{array}$ & $\begin{array}{l}0.0437 \\
(0.0743)\end{array}$ & $\begin{array}{l}0.0376 \\
(0.0747)\end{array}$ \\
\hline Head ed. secondary & $\begin{array}{l}0.0686 \\
(0.103)\end{array}$ & $\begin{array}{l}0.0656 \\
(0.0955)\end{array}$ & $\begin{array}{l}0.0613 \\
(0.0969)\end{array}$ \\
\hline Av. women with primary ed. & $\begin{array}{l}-0.149^{*} \\
(0.0606)\end{array}$ & $\begin{array}{l}-0.140^{*} \\
(0.0622)\end{array}$ & $\begin{array}{c}-0.110+ \\
(0.0606)\end{array}$ \\
\hline No. of children $0-5$ & $\begin{array}{l}0.0196 \\
(0.0162)\end{array}$ & $\begin{array}{l}0.0203 \\
(0.0158)\end{array}$ & $\begin{array}{l}0.0150 \\
(0.0163)\end{array}$ \\
\hline No. of children 6-15 & $\begin{array}{l}0.0895^{* * *} \\
(0.0142)\end{array}$ & $\begin{array}{l}0.0922^{* * *} \\
(0.0147)\end{array}$ & $\begin{array}{l}0.0881^{* * *} \\
(0.0145)\end{array}$ \\
\hline No. of adults & $\begin{array}{l}0.00412 \\
(0.0121)\end{array}$ & $\begin{array}{l}-0.000273 \\
(0.0138)\end{array}$ & $\begin{array}{l}0.00249 \\
(0.0132)\end{array}$ \\
\hline 2nd Expenditure quint. & $\begin{array}{l}-0.0726^{*} \\
(0.0337)\end{array}$ & $\begin{array}{l}-0.0771^{*} \\
(0.0326)\end{array}$ & $\begin{array}{l}-0.0720^{*} \\
(0.0322)\end{array}$ \\
\hline 3rd Expenditure quint. & $\begin{array}{l}-0.0853^{*} \\
(0.0373)\end{array}$ & $\begin{array}{l}-0.0924^{*} \\
(0.0376)\end{array}$ & $\begin{array}{l}-0.0847^{*} \\
(0.0374)\end{array}$ \\
\hline 4th Expenditure quint. & $\begin{array}{l}-0.170^{* * *} \\
(0.0426)\end{array}$ & $\begin{array}{l}-0.178^{* * *} \\
(0.0413)\end{array}$ & $\begin{array}{l}-0.172^{* * *} \\
(0.0411)\end{array}$ \\
\hline 5th Expenditure quint. & $\begin{array}{l}-0.144^{*} \\
(0.0601)\end{array}$ & $\begin{array}{l}-0.152^{*} \\
(0.0612)\end{array}$ & $\begin{array}{l}-0.134^{*} \\
(0.0646)\end{array}$ \\
\hline Log of Remittances & $\begin{array}{l}-0.00113 \\
(0.00458)\end{array}$ & $\begin{array}{l}-0.000379 \\
(0.00450)\end{array}$ & $\begin{array}{l}-0.00112 \\
(0.00452)\end{array}$ \\
\hline 2009 & $\begin{array}{l}0.145^{* * *} \\
(0.0300)\end{array}$ & $\begin{array}{l}0.148^{* * *} \\
(0.0295)\end{array}$ & $\begin{array}{l}0.132^{* * *} \\
(0.0301)\end{array}$ \\
\hline 2010 & $\begin{array}{l}0.221^{* * *} \\
(0.0369)\end{array}$ & $\begin{array}{l}0.221^{* * *} \\
(0.0371)\end{array}$ & $\begin{array}{l}0.210^{* * *} \\
(0.0380)\end{array}$ \\
\hline 2011 & $\begin{array}{l}-1.953^{* * *} \\
(0.159)\end{array}$ & $\begin{array}{l}-1.939^{* * *} \\
(0.155)\end{array}$ & $\begin{array}{l}-2.071 \\
0\end{array}$ \\
\hline Observations & 7217 & 7217 & 7217 \\
\hline
\end{tabular}

Significance level: $.1+.05^{*} .01^{* *} .001^{* * *}$. Robust S.E. in parenthesis. 